Mar. Drugs 2009, 7, 24-44; doi:10.3390/md7010024

Marine Drugs

ISSN 1660-3397

www.mdpi.com/journal/marinedrugs

Article

\title{
Actinomycetes for Marine Drug Discovery Isolated from Mangrove Soils and Plants in China
}

\author{
Kui Hong ${ }^{1 *}$, An-Hui Gao ${ }^{2}$, Qing-Yi Xie ${ }^{1}$, Hao Gao ${ }^{3}$, Ling Zhuang ${ }^{1}$, Hai-Peng Lin ${ }^{1}$, Hai-Ping \\ $\mathrm{Yu}^{2}$, Jia Li ${ }^{2}$, Xin-Sheng Yao ${ }^{3}$, Michael Goodfellow ${ }^{4}$, and Ji-Sheng Ruan ${ }^{1,5}$ \\ ${ }^{1}$ Institute of Tropical Bioscience and Biotechnology, Chinese Academy of Tropical Agriculture \\ Sciences, Haikou 571101, P.R.China; xie-qy@sohu.com; linhp010612@gmail.com \\ ${ }^{2}$ National Center for Drug Screening, Shanghai Institute of Materia Medica, Shanghai 201203, China \\ E-mails: ahgao@mail.shcnc.ac.cn; hpyu@mail.shcnc.ac.cn; jli@mail.shcnc.ac.cn \\ ${ }^{3}$ Institute of Traditional Chinese Medicine \& Natural Products, College of Pharmacy, Jinan University, \\ Guangzhou 510632, P.R. China; E-mail: ghao@mail.tsinghua.edu.cn, tyaoxs@jnu.edu.cn \\ ${ }^{4}$ University of Newcastle, Newcastle upon Tyne NE1 7RU, UK; E-mail: m.goodfellow@ncl.ac.uk \\ ${ }^{5}$ Institute of Microbiology, Chinese Academy of Sciences, Beijing, 100081, P.R. China; E-mail: \\ jishengruan@yahoo.com.cn \\ * Author to whom correspondence should be addressed; E-mail: k1022@163.net.
}

Received: 11 December 2008; in revised: 20 January 2009 / Accepted: 21 January 2009 / Published: 3 February 2009

\begin{abstract}
The mangrove ecosystem is a largely unexplored source for actinomycetes with the potential to produce biologically active secondary metabolites. Consequently, we set out to isolate, characterize and screen actinomycetes from soil and plant material collected from eight mangrove sites in China. Over 2,000 actinomycetes were isolated and of these approximately $20 \%, 5 \%$, and 10\% inhibited the growth of Human Colon Tumor 116 cells, Candida albicans and Staphylococcus aureus, respectively, while 3\% inhibited protein tyrosine phosphatase 1B (PTP1B), a protein related to diabetes. In addition, nine isolates inhibited aurora kinase A, an anti-cancer related protein, and three inhibited caspase 3, a protein related to neurodegenerative diseases. Representative bioactive isolates were characterized using genotypic and phenotypic procedures and classified to thirteen genera, notably to the genera Micromonospora and Streptomyces. Actinomycetes showing cytotoxic activity were assigned to seven genera whereas only Micromonospora and Streptomyces strains showed anti-PTP1B activity. We conclude that actinomycetes isolated from mangrove habitats are a potentially rich source for the discovery of anti-infection and anti-tumor compounds, and of agents for treating neurodegenerative diseases and diabetes.
\end{abstract}


Keywords: Mangroves; actinomycete diversity; marine drug discovery; high-throughput screening; growth inhibition; protein tyrosine phosphatase 1B; aurora kinase A; caspase 3

\section{Introduction}

It is indisputable that new drugs, notably antibiotics, are urgently needed to halt and reverse the relentless spread of antibiotic resistant pathogens which cause life threatening infections and risk undermining the viability of healthcare systems [1]. Filamentous bacteria belonging to the order Actinomycetales, especially Micromomospora and Streptomyces strains, have a unique and proven capacity to produce novel antibiotics [2-4], hence the continued interest in screening such organisms for new bioactive metabolites [5, 6]. However, it is becoming increasingly difficult to discover commercially significant secondary metabolites from well known actinomycetes as this practice leads to the wasteful rediscovery of known bioactive compounds, thereby emphasizing the need to isolate, characterize and screen reperesentatives of undiscovered actinomycete taxa. It is also becoming increasingly clear that un- and under-explored habitats, such as desert biomes and marine ecosystems, are a rich source of novel actinomycetes which have the capacity to produce interesting new bioactive compounds, including antibiotics [7-10].

Molecular ecological studies on community DNA extracted from deep-sea sediments revealed the presence of an astonishingly rich diversity of actinomycete taxa, most of which were predicted to represent novel species, genera and families $[11,12]$. It is not surprising, therefore, that new species of known actinomycete genera isolated from marine habitats are being described on a regular basis [13-18]. There is also a steady stream of proposals for the recognition of new genera, as exemplified by the isolation of the Demequina from tidal mud flats [19], Serinicoccus from surface sea water [20] and Salinispora from oceanic sediments [21]. Representatives of these genera have an obligate requirement for salt, as do deep sea polar strains of Dietzia and Rhodococcus [22]. It has also been shown that nearly $60 \%$ of actinomycetes isolated from sediment samples collected from around the island of Guam in the Pacific Ocean required seawater for growth [23].

It is perhaps not surprising that novel marine actinomycetes are proving to be such a valuable source of new bioactive compounds [24-26] as actinomycete systematics is providing a taxonomic road map to genes hence products, including the discovery of first-in-class drug candidates [9, 27-29]. Indeed, an encouraging flow of novel anti-infection and anti-cancer compounds are being sourced from marine actinomycetes, as exemplified by the discovery of the abbysomicins, potent polycyclic polyketides active against methicillin-resistant Staphylococcus aureus and produced by "Verrucosispora maris" [30] and salinosporamide A, an anti-cancer compound produced by Salinispora tropica [31]. Marine Verrucosispora strains are also a source of novel proximicins, anti-tumor furan analogues of the antibiotic netropsin [32].

The discovery of novel microbial natural products is encouraged not only by the quality of biological material but also by the novelty of screening models. Many new molecular targets have been designed to detect anti-microbial and cytotoxic activities [33], and to highlight chemical entities for the treatment of conditions such as diabetes and degenerative diseases. Caspase 3, a key protease 
involved in programmed cell death of neuronal apoptosis, for instance, is a promising target for the treatment of neurodegenerative diseases [34]. Similarly, potent and selective protein tyrosine phosphatase 1B inhibitors are potential therapy for the treatment of type- 2 diabetes and obesity [35-37].

Mangroves, unique woody plant communities of intertidal coasts in tropical and subtropical coastal regions, are highly productive ecosystems [38, 39] though surprisingly little is known about the microbial communities living therein [40-42], although there is evidence that mangrove sediments contain high populations of micromonosporae [43] and novel actinomycetes, as illustrated by the isolation of Asanoa iriomotensis [44] and Nonomuraea maheshkhaliensis [13]. It is also encouraging that bioactive compounds have been obtained from mangrove plants [44-46], fungi [47-50], and bacteria [51], including actinomycetes [14, 52].

During 2001-2005, "China Sea" and "microorganism" showed the highest percentage of source region and source phyla citations, respectively, with respect to the total of marine natural products for 1965-2005 [24]. The rich mangrove flora of South-East China is composed of 26 plant species which are classified into 15 genera and 12 families [39]. All but one of the plant species, including four endemic ones, are found in mangroves located around the coast of Hainan Island. The primary aim of the present study was to determine whether actinomycetes isolated from environmental samples collected from mangrove forests in Fujian, Guangdong, Guangxi and Hainan Provinces in China showed biological activities. To this end, a range of selective isolation and characterization procedures were used to recover and identify diverse actinomycetes from plant and soil samples prior to establishing their activities in a number of biological screening assays. Representative isolates found to be active against tumor cells and a diabetes related protein were fully characterized using established chemotaxonomic, morphological and molecular systematic methods.

\section{Results}

\subsection{Selective isolation of actinomycetes}

A total of 2,041 actinomycetes were isolated from 112 soil and 99 plant samples collected from the eight mangrove sites, the average number of isolates per sample was 9.7 (2,041 from 211) (Table 1). The highest average number of actinomycetes, 21.8 (1,004 from 46), was obtained from the rhizosphere soil samples, and the lowest number, 4.5 (434 from 99), from the plant tissues samples. It is apparent that the number of endophytic actinomycetes isolated from plant tissues is much less than those recovered from the composite soil samples. The highest average number of isolates were obtained from the composite soil samples collected from the Fujian mangrove (93 isolates from 3 samples), and the lowest number from the corresponding Guangxi sample (62 isolates from 17 samples). In total, 603 actinomycetes were isolated from the composite soil samples giving an average nearly of 9.3 strains per sample. 
Table 1. Selective isolation of actinomycetes from mangrove environmental samples.

\begin{tabular}{lllll}
\hline \multirow{2}{*}{ Sites } & \multicolumn{4}{l}{ Number of samples / Number of isolated actinomycetes } \\
\cline { 2 - 5 } & Composite & Rizhosphere & Plant & Total \\
& soil & soil & tissues & \\
\hline Danzhou & $5 / 40$ & $\mathrm{ND}$ & $\mathrm{ND}$ & $5 / 40$ \\
Fujian & $3 / 93$ & $\mathrm{ND}$ & $\mathrm{ND}$ & $3 / 93$ \\
Guangxi & $17 / 62$ & $5 / 27$ & $4 / 4$ & $26 / 93$ \\
Haikou & $3 / 25$ & $5 / 16$ & $2 / 11$ & $10 / 52$ \\
Sanya & $3 / 78$ & $\mathrm{ND}$ & $\mathrm{ND}$ & $3 / 78$ \\
Shenzhen & $4 / 57$ & $5 / 44$ & $8 / 48$ & $17 / 149$ \\
Wenchang & $26 / 205$ & $31 / 917$ & $62 / 256$ & $119 / 1378$ \\
Zhanjiang & $5 / 43$ & $\mathrm{ND}$ & $23 / 115$ & $28 / 158$ \\
Total & $66 / 603$ & $46 / 1004$ & $99 / 434$ & $211 / 2041$ \\
\hline
\end{tabular}

\subsection{Bioactivity of strains isolated from the mangrove sites}

All of the isolates were examined to determine their activities in five high throughput screening models, namely against Human Colon Tumor (HCT) 116 cells, Candida albicans ATCC 10231, Staphylococcus aureus ATCC 51650, protein tyrosine phosphatase (PTP1B) and caspase 3. Three hundred and forty three strains showed activity against the tumor cell line (16.8\%), 198 against $S$. aureus (9.7\%), 101 against $C$. albicans (4.9\%), and 59 against PTP1B (2.9\%); only 3 isolates inhibited caspase 3 . In addition, 9 out of the 343 cytotoxic strains showed activity against aurora kinase A, a protein related to an indicator of anti-cancer activity. Some of the isolates exhibited activities in more than one of the screens.

Figure 1. Percentage of bioactive strains isolated from composite soil samples collected from the mangrove sites. The percentages indicate the number of positive hits against each of 4 targets over the total number of strains isolated at each site.

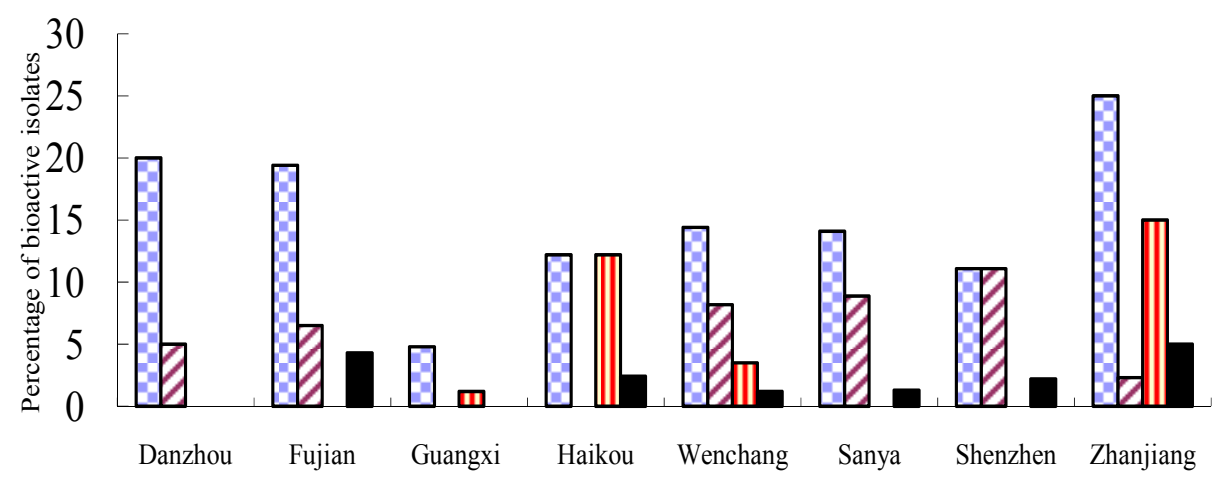

Soil samples

\begin{tabular}{|lll|}
\hline aCytotoxicity $\quad \boldsymbol{\Delta}$ Anti-S. aureus & $\mathbf{\square}$ Anti-C.albicans & $\mathbf{0 P T P} 1 \mathrm{~B}$ inhibition \\
\hline
\end{tabular}

The highest percentage of anti-tumor and anti- C. albicans activity was found with strains isolated from samples collected from Zhanjiang. Isolates from the Wenchang samples showed activity against 
all of the screening models, including two out of the three isolates inhibit on caspase 3, possibly reflecting the diverse nature of the plant species growing at these well preserved locations (Figure 1). In contrast, the lowest number of bioactive strains was recorded from the Guangxi samples; it was noted that the soil from this location contained more sand and less organic matter than those from other sites.

It can be seen from Table 2 that a higher percentage of bioactive strains were isolated from the plant tissues compared with those isolated from the corresponding rhizosphere soil samples with respect strains isolated from the Wenchang samples but with two exceptions of cytotoxicity and PTP1B inhibition from the Zhangjiang samples.

Table 2. Percentage of bioactive strains isolated from plant tissues against those isolated from corresponding rhizosphere soil.

\begin{tabular}{llcccc}
\hline $\begin{array}{l}\text { Sampling } \\
\text { sites }\end{array}$ & Sample type & $\begin{array}{c}\text { Anti- } \\
\text { C. albicans }\end{array}$ & $\begin{array}{c}\text { Anti- } \\
\text { S. aureus }\end{array}$ & $\begin{array}{c}\text { Anti- } \\
\text { tumor cell }\end{array}$ & $\begin{array}{l}\text { PTP1B } \\
\text { inhibition }\end{array}$ \\
\hline \multirow{2}{*}{ Wenchang } & Plant tissues & 9.8 & 16.0 & 22.2 & 1.6 \\
& Rhizosphere soil & 3.5 & 8.2 & 14.4 & 1.2 \\
\multirow{2}{*}{ Zhangjiang } & Plant tissues & 20.0 & 37.4 & 4.3 & $/$ \\
& Rhizosphere soil & 15.0 & 2.3 & 25.0 & 5.0 \\
\hline
\end{tabular}

\subsection{Bioactivity of actinomycetes isolated from the 23 mangrove plant species}

Higher total number of bioactive actinomycetes was obtained from the rhizosphere soil than from plant materials collected from the 23 mangrove plant species with the exception of anti-C. albicans. Strains isolated from either the rhizosphere soil or the plant tissues of Acanthus ilicifolius showed activity in all of the assays, apart from caspase 3.

Table 3. Number of bioactive actinomycetes isolated from rhizosphere soils and plant tissues of 23 mangrove plant species.

\begin{tabular}{|c|c|c|c|c|c|c|c|c|}
\hline \multirow[b]{3}{*}{ Mangrove plant species } & \multicolumn{8}{|c|}{ Number of Bioactive actinomycetes } \\
\hline & \multicolumn{4}{|c|}{ Rhizosphere soil } & \multicolumn{4}{|c|}{ Plant tissues } \\
\hline & 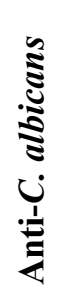 & 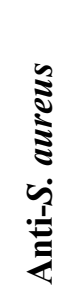 & 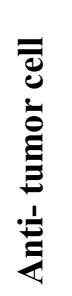 & 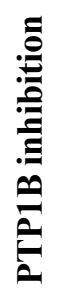 & 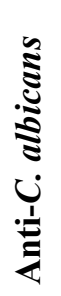 & 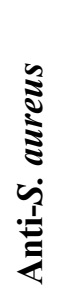 & 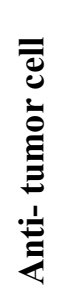 & 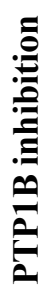 \\
\hline Acanthus ilicifolius & 1 & 5 & 13 & 2 & 6 & 3 & 5 & 3 \\
\hline Acrostichum aureum & 0 & 0 & 0 & 0 & 2 & 1 & 0 & 0 \\
\hline Acrostichum speciosum & 0 & 2 & 7 & 0 & 0 & 2 & 2 & 0 \\
\hline Aegiceras corniculatum & 3 & 15 & 5 & 0 & 5 & 11 & 10 & 0 \\
\hline Avicennia marina & 1 & 0 & 0 & 0 & 4 & 7 & 1 & 0 \\
\hline
\end{tabular}


Table 3. Cont.

\begin{tabular}{lrrrrrrrrr}
\hline Barringtonia racemosa & 0 & 0 & 1 & 0 & ND & ND & ND & ND \\
\hline Bruguiera gymnorrhiza & 2 & 4 & 5 & 0 & 12 & 15 & 6 & 1 \\
\hline Bruguiera sexangula & 1 & 2 & 12 & 2 & 0 & 0 & 1 & 0 \\
\hline Cerbera manghas & 5 & 0 & 4 & 3 & 1 & 4 & 4 & 0 \\
\hline Ceriops tagal & 0 & 0 & 0 & 0 & 2 & 1 & 1 & 0 \\
\hline Excoecaria agallocha & 0 & 0 & 3 & 0 & 0 & 3 & 2 & 0 \\
\hline Heritiera littoralis & 13 & 26 & 22 & 2 & 3 & 3 & 2 & 0 \\
\hline Hibiscus tilisaceus & 6 & 16 & 33 & 4 & 7 & 4 & 7 & 0 \\
\hline Kandelia candel & 0 & 0 & 1 & 0 & 2 & 4 & 1 & 0 \\
\hline Lumnitzera racemosa & 0 & 0 & 0 & 0 & 0 & 2 & 2 & 1 \\
\hline Pongamia pinnata & 0 & 7 & 6 & 0 & 0 & 2 & 2 & 0 \\
\hline Rhizophora apiculata & 0 & 2 & 11 & 3 & 0 & 1 & 2 & 0 \\
\hline Rhizophora stylosa & $\mathrm{ND}$ & $\mathrm{ND}$ & $\mathrm{ND}$ & $\mathrm{ND}$ & 7 & 14 & 3 & 0 \\
\hline Sonneratia alba & 7 & 12 & 10 & 0 & 0 & 2 & 3 & 0 \\
\hline Sonneratia caseolaris & 1 & 4 & 6 & 1 & 0 & 3 & 4 & 0 \\
\hline Sonneratia hainanensis & 0 & 0 & 0 & 0 & 0 & 0 & 0 & 0 \\
\hline Sonneratia paracaseolaris & 2 & 4 & 5 & 0 & 0 & 4 & 1 & 0 \\
\hline Xylocarpus granatum & 0 & 0 & 0 & 0 & 4 & 2 & 3 & 0 \\
\hline Total & 42 & 99 & 144 & 17 & 55 & 88 & 62 & 5 \\
\hline
\end{tabular}

The highest number of bioactive strains was observed from the rhizosphere soil of Heritiera littoralis. High numbers of bioactive strains were found in all of the assays, apart from caspase 3, in the case of isolates from the rhizosphere soil of Heritiera littoralis, and from the plant tissues of Bruguiera gymnorrhiza. In contrast, bioactive actinomycetes were not obtained from the rhizosphere soil or the plant tissues of Sonneratia hainanensis, an endemic plant in Hainan mangrove forests (Table 3).

\subsection{Taxonomic diversity of bioactive actinomycetes}

Two hundred and thirty seven isolates selected on the basis of their metabolites bioactivities were identified using chemotaxonomic (presence of isomers of diaminopimelic acid and diagnostic whole-organism sugars) and morphological (as seen by light microscopy) markers, and by 16S rRNA gene sequence data. The results showed that the tested isolates belonged to 13 genera classified into 7 families and 5 suborders (Table 4). It is clear from the table that the highest activities were shown by isolates assigned to the genera Micromonospora and Streptomyces. However, it is also interesting that the Actinomadura, Nocardia and Nonomuraea isolates showed anti-tumor cell activity. 
Table 4. Identification of representative bioactive actinomycetes isolated from Chinese mangroves.

\begin{tabular}{|c|c|c|c|c|c|c|c|}
\hline \multirow[t]{2}{*}{ Genera } & \multirow[t]{2}{*}{ Families } & \multirow[t]{2}{*}{ Suborders } & \multicolumn{5}{|c|}{$\begin{array}{c}\text { Number of the identified } \\
\text { representative strains }\end{array}$} \\
\hline & & & 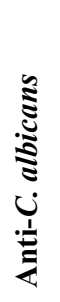 & 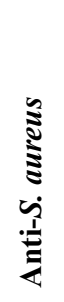 & 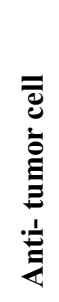 & 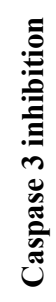 & 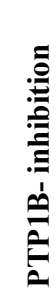 \\
\hline Actinomadura & Thermomonosporaceae & Streptosporangineae & & & 3 & & \\
\hline Microbispora & & & & & & 1 & \\
\hline Nonomuraea & Streptosporangiaceae & & & & 1 & & \\
\hline Actinoplanes & Micromonosporaceae & Micromonosporineae & 1 & & & & \\
\hline Micromonospora & & & 7 & 10 & 25 & 1 & 8 \\
\hline Verrucosispora & & & & & 1 & & \\
\hline Arthrobacter & Micrococcaceae & Micrococcineae & & 1 & & & \\
\hline Isoptericola & & & 1 & & & & \\
\hline Micrococcus & & & 1 & & & & \\
\hline Microbacterium & Microbacteriaceae & & 1 & & & & \\
\hline Nocardia & Nocardiaceae & Corynebacterineae & & & 5 & & \\
\hline Rhodococcus & & & & 1 & 1 & & \\
\hline Strepomyces & Streptomycetaceae & Streptomycineae & 1 & 7 & 45 & 1 & 4 \\
\hline
\end{tabular}

$2.516 S$ rRNA gene sequencing of representative isolates showing activity against tumor cells

The most taxonomically diverse actinomycetes were those showed activity against the tumor cells. It can be seen from Figure 2 that the 26 tested strains which gave positive results were assigned to 7 genera with just over half of them belonging to the genus Streptomyces. Most of the Streptomyces isolates formed distinct phyletic lines though strain 172621 was found to have an identical sequence to that of the type strain of $S$. coelicolor. Similarly, the 6 isolates belonging to the genus Micromonospora formed a diverse group, as did the 4 Nocardia isolates. It was interesting that the single isolate assigned to the genus Actinomadura had an identical 16S rRNA gene sequence to the type strain of $A$. glauciflava. In contrast, the single isolates belonging to the genera Nonomuraea, Rhodococcus, and Verrucosispora formed relatively distinct phyletic lines. 
Figure 2. Neighbor-joining tree based on almost complete 16S rRNA gene sequences showing relationships between the 26 selected actinomycetes found to inhibit tumor cells in vitro, and between them and the type strains of the highest 16S rDNA sequence similarity. Numbers at the nodes indicate bootstrap values based on 1000 replicates; only values above $50 \%$ are shown. Bar, $1 \%$ sequence divergence.

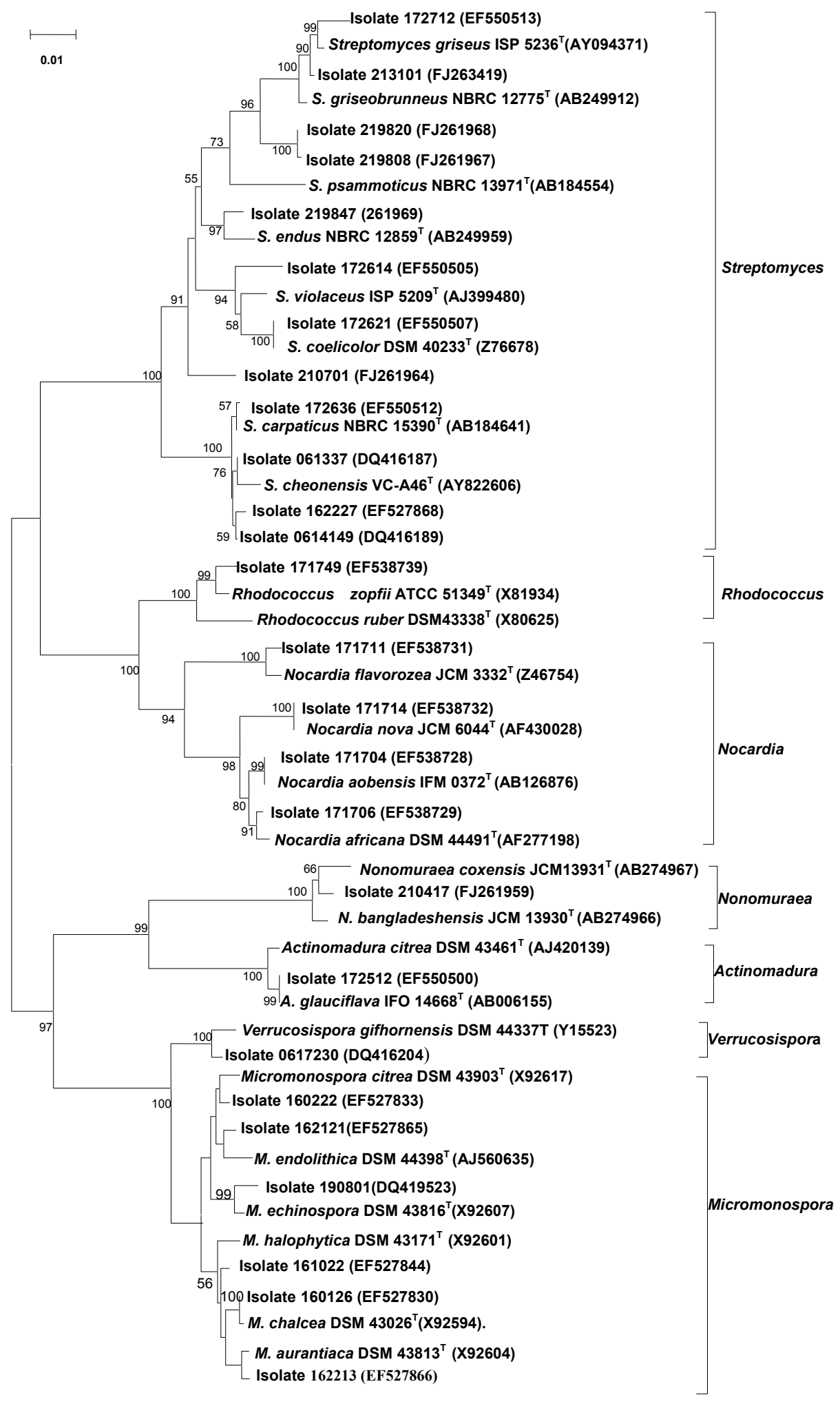


Some of the Streptomyces isolates were assigned to $16 \mathrm{~S}$ rRNA subclades which reflected the sites from which they were isolated. In particular, the three strains from Wenchang, isolates 061337, 0614149 and 162227 , formed a distinct subclade together with the type strain of S. cheonensis, a taxon supported by a $100 \%$ bootstrap value. Similarly, isolates 172614 and 172621 from the Shenzhen composite soil constituted a well delineated subclade together with the type strains of S. coelicolor and $S$. violaceus. The four strains isolated from the Sanya composite soil sample were part of a more diffuse subclade which encompassed the type strains of $S$. endus, $S$. griseobrunneus, $S$. griseus and $S$. psammoticus (Figure 2). Most of the Micromonospora strains which showed activity against tumor cells were isolated from the roots of mangrove plants, i.e., Acrostichum aureum (isolate160126), Acrostichum speciosum (isolate 160222), Cerbera manghas (isolate 162121), Lumnitzera racemosa (isolate 161022) and Rhizophora stylosa (162223). More micromonosporae than streptomycetes were isolated from the plant material.

\subsection{S rRNA gene sequences of isolates which inhibited protein tyrosine phosphatase 1B}

The 12 actinomycetes those metabolites active in the PTP1B screen were assigned to the genera Micromonospora and Streptomyces (Figure 3). Six out of the 8 Micromonospora strains formed relatively distinct phyletic lines though isolates 201806 and 215009 had identical 16S rRNA gene sequences to one another and to the type strain of $M$. chalcea. The 4 Streptomyces isolates were relatively closely related to the type strains of Streptomyces species. Indeed, isolate 172610 had an identical 16S rRNA gene sequence to the type strain of $S$. albus whereas isolate 216802 had a nearly identical sequence to $S$. violaceochromogenes $\mathrm{NBRC} 13100^{\mathrm{T}}$.

\section{Discussion}

Considerable attention is currently being paid to the isolation and characterization of novel actinomycetes from poorly researched habitats given the premise that screening such organisms raises the prospect of discovering new natural products that can be developed as a resource for biotechnology $[7,10,43]$. This reasoning appears to be sound as novel actinomycetes isolated from unexplored marine habitats are proving to be a valuable source of new bioactive metabolites $[9,26]$. It seems timely, therefore, to extend this approach to another poorly studied environment, the mangrove ecosystem. Mangroves develop along estuaries in tropical and subtropical regions where sea water and fresh water mix. Indeed, mangrove forests may become an invaluable source for discovering novel actinomycetes hence new chemodiversity should salinity prove to be a driver of bacterial diversity as proposed by Lozupone and Knight [53].

It was not intended in the present investigation to assemble a detailed inventory of the kinds of actinomycetes found in the mangrove ecosystem or to isolate and characterize novel bioactive compounds, but the study was designed to prepare the ground for such studies by isolating, partially characterizing and screening a diverse range of actinomycetes. Even so, this investigation does provide the most comprehensive survey of culturable actinomycetes present in mangrove forests, a result which probably reflects the application of a broad range of selective isolation procedures to many environmental samples. 
Figure 3. Neighbor-joining tree based on nearly complete 16S rRNA gene sequences showing relationships between the 12 isolates active in the PIP1B assay and between them and the highest 16S rDNA sequence similar Micromonospora and Streptomyces species. Bifidobacterium bifidum DSM $20456^{\mathrm{T}}$ (M38018) was used as the outgroup. Numbers at the nodes are percentage bootstrap values based on 1,000 replicates; only values $50 \%$ or above are given. Bar, $2 \%$ sequence divergence.

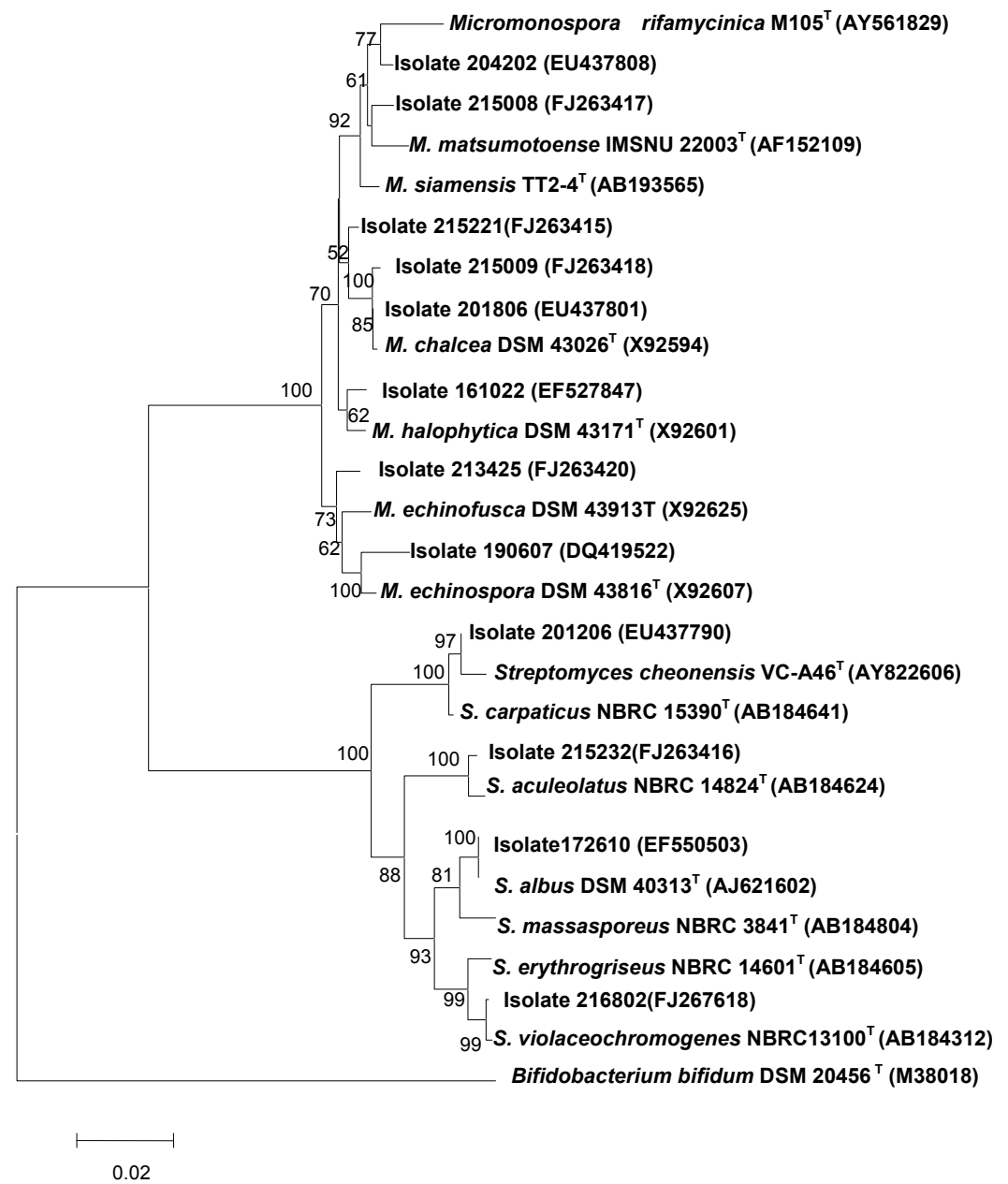

In total, representatives of 13 established actinomycete genera belonging to 7 families and 5 suborders were recognized out of the bioactive isolates. The presence of predominant numbers of Micromonospora and Streptomyces strains amongst the isolates is in line with the results reported by Eccleston et al. [43]. Asanoa and Gordonia can be added to the list of genera isolated from mangroves though the representatives of these taxa did not show any biological activity from the present screening, thus provides further evidence that such organisms are present in the mangrove ecosystem [13, 18].

Many of the strains isolated in the present study showed bioactivity against one or more of the screening systems, thereby underpinning and extending results from previous studies which showed mangroves to be a source of bioactive actinomycetes [14, 43]. Thus, 343 isolates showed activity against the tumor cell line (16.8\%), 101 against C. albicans ATCC 10231(4.9\%), 198 against $S$. aureus ATCC 51650 (9.7\%), 59 against PTP1B (2.9\%); but only 3 and 9 strains were active against caspase 3, and aurora kinase A, respectively. The lower inhibition frequencies of biochemical assays on molecular level comparing to growth inhibition assays on cell level are acceptable considering their higher 
selectivity. The most active strains belonged to the genera Micromonospora and Streptomyces. Indeed, members of these taxa showed activity against caspase 3 and protein tyrosine phosphatase 1B. In contrast, representatives of seven genera, namely Actinomadura, Micromonospora, Nocardia, Nonomuraea, Rhodococcus, Streptomyces and Verrucosispora, were active against the tumor cell line.

The distribution of bioactive actinomycetes showed some relationship to the nature and source of the environmental samples. The highest percentage of isolates showing anti-tumor and anti- $C$. albicans activity, for example, were from the Zhangjiang mangrove. Isolates from this site and from the mangrove at Wenchang were particularly effective in the anti-infective and anti-cancer assays. Similarly, higher numbers of bioactive strains were obtained from rhizosphere samples than from corresponding plant materials. The rhizosphere soil from Heritiera littoralis was a particularly rich source of bioactive strains. These results are not only interesting but will also guide future bioprospecting strategies.

It is becoming increasingly evident that the taxonomic and metabolic diversity encompassed by streptomycetes is remarkable, as new and putatively novel Streptomyces species are being continuously isolated from under-researched habitats and shown to be valuable sources of new bioactive compounds $[8,10,26]$. The $16 \mathrm{~S}$ rRNA gene sequence data acquired in the present study provided further evidence of this trend. Thus many of the streptomycetes which showed activity in the anti-tumor assay can be assigned to new species as they are separated from the type strains phylogenetic neighbors by sequence similarities well below those found between closely related Streptomyces species, such as those classified in the $S$. violaceusniger subclades [27, 28] and S. griseus [54]. The highest 16S rDNA sequence similarity to the valid species of Streptomyce violaeus of isolate 172614 and isolate 210701 were lower than 0.97 as 0.95 and 0.968 , respectively. Though the highest 16S rDNA sequence similarity of isolates of 219820 and 219808 to the type strain of $S$. griseobrunneus NBRC $12775^{\mathrm{T}}$ were a little higher than 0.97 , with the values of 0.977 and 0.976 , respectively, they were highly lower than the similarity of most of the known closely related streptomycetes species [54]. Isolates 162227 and 0614149 formed a distinct branch with the highest 16S rDNA sequence similarity of 0.985 and 0.99 , respectively, to the type strain of $S$. carpaticus NBRC15390 ${ }^{\mathrm{T}}$, but confirmed to be a new species by the DNA-DNA pairing value lower than $70 \%$ (data not shown). It is also interesting that some of the Streptomyces isolates were assigned to $16 \mathrm{~S}$ rRNA subclades which corresponded to the sites from which the strains were isolated. These observations while tentative might reflect an endemic and /or environmental selection of Streptomyces species. In this context, it should be noted that evidence has been presented for niche varieties between S. griseus strains [55].

It is evident from the 16S rRNA gene sequence data that many of the Micromonospora isolates active in the anti-tumor and PTP1B assays belong to putatively new species of this genus. Indeed, this also applies to isolates assigned to some of other taxa, such as the genera Rhodococcus, Nomomuraea and Verrucosispora, thereby indicating that mangrove habitats are likely to be a good source of rare actinomycetes. Taxonomic descriptions of new species discovered in this study will be the subject of subsequent publications. At present, detailed conclusions regarding the distribution and ecology of actinomycete taxa in mangrove habitats is premature. However, it is clear from the present study that actinomycetes isolated from mangrove habitats can be expected to provide high quality biological material for high through put biochemical, anti-cancer and anti-infection screening programmes. 


\section{Experimental Section}

\subsection{Collection of samples}

Soil samples were collected from mangrove sites at Danzhou, Haikou, Sanya and Wenchang in Hainan Province; Shenzhen and Zhanjiang in Guangdong Province; Xiameng in Fujian Province, and Beihai in Guangxi Province (Figure 4). At each location, five soil core samples were collected at a depth of 0-30 cm within a $100 \mathrm{~m}^{2}$ area. The soils from each location were bulked and homogenized to prepare composite samples. In addition, leaf, stem, roots, and where relevant flowers and fruits, were collected together with rhizophere soil from plant species growing in the mangrove forest at Wenchang, Hainan Province (Table 5). The soil and plant tissue samples were either examined on the day of sampling or on the following day. Samples were stored at $4{ }^{\circ} \mathrm{C}$ in the dark prior to examination.

Figure 4. Location of sampling sites.

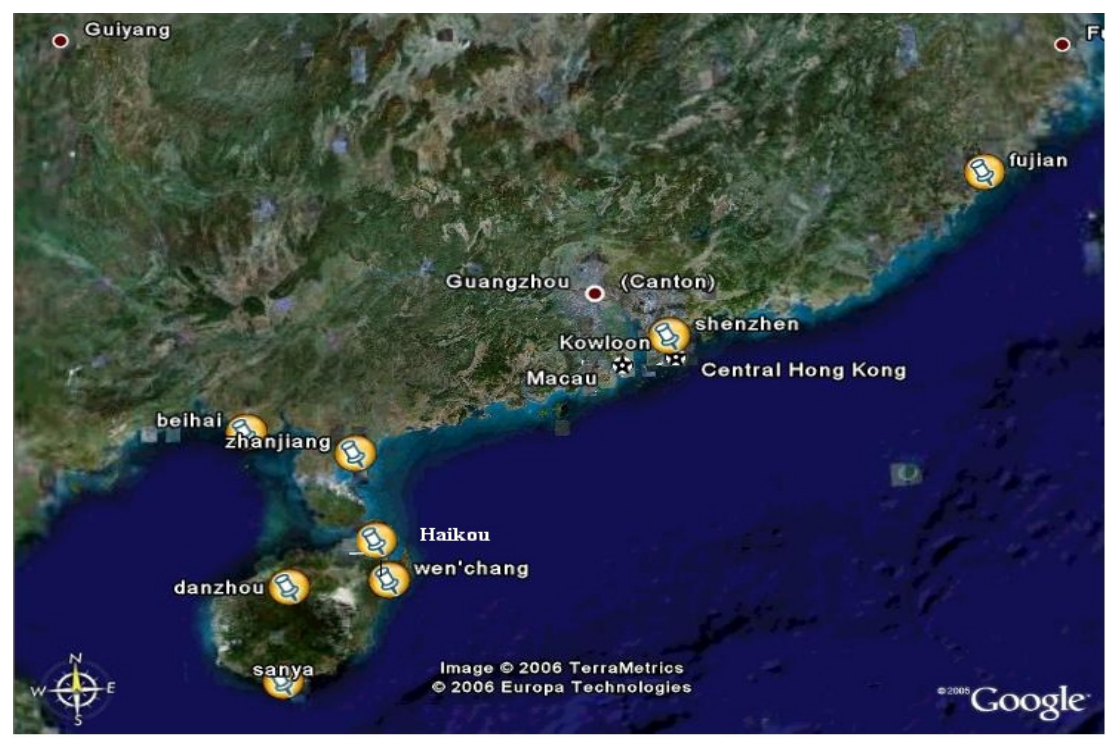

Table 5. Source of plant materials and soils collected from the mangrove forest at Wenchang, Hainan Province.

\begin{tabular}{ll}
\hline Genus and Species & Samples \\
\hline Acanthus ilicifolius & Rhizosphere soil, roots, leaves and flowers \\
$\begin{array}{ll}\text { Acrostichum aureum } \\
\text { Acrostichum speciosum } \\
\text { Aegiceras corniculatum }\end{array}$ & Rhizosphere soil, roots and leaves \\
\hline $\begin{array}{l}\text { Avicennia marina } \\
\text { Barringtonia racemosa }\end{array}$ & Rhizosphere soil, leaves, and fruit \\
$\begin{array}{l}\text { Bruguiera gymnorrhiza } \\
\text { Bruguiera sexangula }\end{array}$ & Rhizosphere soil \\
$\begin{array}{l}\text { Cerbera manghas } \\
\text { Ceriops tagal }\end{array}$ & Rhizosphere soil, roots and leaves \\
\hline Excoecaria agallocha & Rhizosphere soil, roots, leaves, and fruit \\
\hline
\end{tabular}


Table 5. Cont.

\begin{tabular}{ll}
\hline Heritiera littoralis & Rhizosphere soil, leaves, and fruit \\
\hline Hibiscus tilisaceus & Rhizosphere soil, roots and leaves \\
\hline Kandelia candel & Rhizosphere soil and leaves \\
\hline Lumnitzera racemosa & Rhizosphere soil, roots and leaves \\
\hline Pongamia pinnata & Rhizosphere soil and leaves \\
\hline Rhizophora apiculata & Rhizosphere soil and leaves, \\
\hline Rhizophora stylosa & Roots and leaves \\
\hline Sonneratia alba & Rhizosphere soil, leaves, and fruit \\
\hline Sonneratia caseolaris & Rhizosphere soil and leaves \\
\hline Sonneratia hainanensis & Roots and leaves \\
\hline Sonneratia paracaseolaris & Roots, leaves, and fruit \\
\hline Xylocarpus granatum &
\end{tabular}

\subsection{Selective isolation of actinomycetes from environmental samples}

Air dried soil samples were sieved to exclude large mineral and organic matter particles then ground in a pestle and mortar. Selective pretreatments of the soil samples included dry heat $\left(120^{\circ} \mathrm{C}\right.$, $60 \mathrm{~min}$ ) [56], treatments with Chloramine-T [57]; phenol (1.5\%, $30 \mathrm{~min}$ at $\left.30^{\circ} \mathrm{C}\right)$ [56]; $0.05 \% \mathrm{SDS}$ and $6 \%$ yeast extract $\left(40{ }^{\circ} \mathrm{C}, 200 \mathrm{rpm}, 30 \mathrm{~min}\right)$ [56], and wet heat in sterilized sea water $\left(50{ }^{\circ} \mathrm{C}, 15\right.$ min) [58]. The pretreated soil samples were diluted 1:10 v/v with sterile 1/4 Ringer's solution and serial dilutions prepared down to $10^{-4}$. One hundred $\mu \mathrm{L}$ of the $10^{-1}-10^{-4}$ suspensions were spread, in triplicate, onto selective isolation media.

The plant tissues were surface cleaned with sterile water and air-dried in a laminar flow hood. The resultant preparations were treated with $75 \%$ ethanol for $5 \mathrm{~min}$, then with $0.1 \% \mathrm{HgCl}_{2}$ for 15 min, prior to washing five times for 5 minutes with sterile 1\% Tween 80 . Five grams of surface sterilized mangrove plant tissues were cut into small pieces, added to $45 \mathrm{~mL} 50 \%$ sterile sea water, and ground into smaller pieces using a pestle and mortar. Fractions $(100 \mu \mathrm{L})$ of the resultant preparations were plated, in triplicate, onto selective isolation plates which had been dried for 30 minutes at room temperature in a laminar flow cabinet.

Dilutions of soil and plant tissues were plated out onto one or more of 11 different selective isolation media (IM1 to IM11):IM1 (oatmeal agar, ISP meduim3) [59]; oatmeal, $60 \mathrm{~g}$; agar, $15 \mathrm{~g}$; pH 7.2 7.4; IM2 (Gause modified medium 1 [60]); soluble starch, $20 \mathrm{~g} ; \mathrm{K}_{2} \mathrm{HPO}_{4}, 0.5 \mathrm{~g} ; \mathrm{KNO}_{3}, 1 \mathrm{~g} ; \mathrm{MgSO}_{4} \cdot 7 \mathrm{H}_{2} \mathrm{O}$, $0.5 \mathrm{~g}$; agar, $20 \mathrm{~g}$; pH7.4 7.6; IM3 (Raffinose-histidine medium[61]); raffinose, $10 \mathrm{~g}$; L-histidine, 1g; $\mathrm{MgSO}_{4} \cdot 7 \mathrm{H}_{2} \mathrm{O}, 0.5 \mathrm{~g} ; \mathrm{FeSO}_{4} \cdot 7 \mathrm{H}_{2} \mathrm{O}, 0.01 \mathrm{~g} ; \mathrm{K}_{2} \mathrm{HPO}_{4}, 1 \mathrm{~g}$; Bacto-agar, $20.0 \mathrm{~g} ; \mathrm{pH} 7.0 \sim 7.4 ; \mathrm{IM} 4,1 / 10$ ATCC 172 medium; glucose, $1 \mathrm{~g}$; soluble starch, $2 \mathrm{~g}$; yeast extract, $0.5 \mathrm{~g}$; $\mathrm{CaCO}_{3}, 1.5 \mathrm{~g}$; agar, $18 \mathrm{~g}$; $\mathrm{N}$-Z-amine, $0.5 \mathrm{~g}$; pH 7.0 7.4, and supplemented with a filter sterilized solution of novobiocin (25 $\mathrm{mg} / \mathrm{ml}$ ); IM5, sea-water agar; sea-water, 1L; agar $18 \mathrm{~g}$; IM6 (Yeast extract-malt estract agar; ISP medium 2[59]); yeast extract, 4 g; malt extract, 30 g; glucose, 4 g; agar, 18 g; pH 7.0 7.4; IM7 (Starch casein agar [62]); starch, $10 \mathrm{~g}$; casein, $3 \mathrm{~g}$; agar, $18 \mathrm{~g}$; pH 7.0 7.4; IM8 [63]; glucose, $10 \mathrm{~g}$; peptone, 5 $\mathrm{g}$; tryptone, $3 \mathrm{~g} ; \mathrm{NaCl}, 5 \mathrm{~g}$; agar, $15 \mathrm{~g} ; \mathrm{pH} \mathrm{7.0,} \mathrm{and} \mathrm{supplemented} \mathrm{with} \mathrm{filter} \mathrm{sterilized} \mathrm{nalidixic} \mathrm{acid}$ $(10 \mathrm{mg} / \mathrm{mL})$ and novobiocin $(10 \mathrm{mg} / \mathrm{mL})$; IM9 (Glucose asparagine agar [58]); glucose, 10g; asparagine, $0.5 \mathrm{~g} ; \mathrm{K}_{2} \mathrm{HPO}_{4}, 0.5 \mathrm{~g}$; agar, $20 \mathrm{~g}$; pH: 7.2 7.4; IM10 (humic acid -vitamin agar [64]); 
humic acid, $1.0 \mathrm{~g} ; \mathrm{CaCO}_{3}, 0.02 \mathrm{~g} ; \mathrm{Na}_{2} \mathrm{HPO}_{4}, 0.5 \mathrm{~g} ; \mathrm{KC} 1,1.7 \mathrm{~g} ; \mathrm{FeSO}_{4} \cdot 7 \mathrm{H}_{2} \mathrm{O}, 0.01 \mathrm{~g} ; \mathrm{MgSO}_{4} \cdot 7 \mathrm{H}_{2} \mathrm{O}, 0.5$ g; agar, $18 \mathrm{~g}$; pH7.2, and supplemented with sterilized vitamins: aminobenzoic acid, inositol, nicotinic acid, riboflavin, pantothenic acid, thiamine, vitamin B6 (at $0.5 \mathrm{mg}$ ) and $0.25 \mathrm{mg}$ of biotin; IM11 (dextran-histidine-sodium chloride-mineral salts agar[65]); $\mathrm{K}_{2} \mathrm{HPO}_{4}, 2 \mathrm{~g} ; \mathrm{KNO}_{3}, 2 \mathrm{~g} ; \mathrm{MgSO}_{4} \cdot 7 \mathrm{H}_{2} \mathrm{O}$, $0.05 \mathrm{~g} ; \mathrm{CaCO}_{3}, 0.02 \mathrm{~g} ; \mathrm{FeSO}_{4} \cdot 7 \mathrm{H}_{2} \mathrm{O}, 0.01 \mathrm{~g}$; agar, $18 \mathrm{~g}$; distilled water, $1 \mathrm{~L} ; \mathrm{pH} 7.2$, and supplemented with dextran, $1 \%$, w/v; L-histidine, $0.1 \%$, w/v; $\mathrm{NaCl}, 3 \%$, w/v; penicillin $\mathrm{G}\left(5 \mathrm{iu} \mathrm{mL}^{-1}\right)$, and rifampicin $(5 \mu \mathrm{g} / \mathrm{mL})$. All of the media, apart from IM5, were supplemented with 50-100 $\mathrm{mg} / \mathrm{L}$ $\mathrm{K}_{2} \mathrm{Cr}_{2} \mathrm{O}_{7}, 50 \mathrm{mg} / \mathrm{L}$ cycloheximide and $25-50 \mathrm{mg} / \mathrm{L}$ nystatin [66], and made up to one liter with $0.5 \mathrm{~L}$ sea-water and $0.5 \mathrm{~L} \mathrm{dH}_{2} \mathrm{O}$.

The inoculated plates were incubated at $28{ }^{\circ} \mathrm{C}$ for one up to twelve weeks. Colonies of streptomycete-like and non-streptomycete-like strains growing on the isolation plates were inoculated onto IM2 and IM6 plates, respectively, and incubated for 7-10 days at $28{ }^{\circ} \mathrm{C}$. Purified cultures were stored either on IM 4 or IM6 agar slants for short term storage and in $20 \%$ glycerol at $-80{ }^{\circ} \mathrm{C}$ for long-term storage.

\subsection{Preparation of crude extracts}

The fermentation medium for primary screening was FM 3 [67]: soluble starch, $20 \mathrm{~g}$; soy powder, $15 \mathrm{~g}$; yeast extract, $5 \mathrm{~g}$; peptone, $2 \mathrm{~g}$; $\mathrm{CaCO}_{3}, 4 \mathrm{~g}$; sea salts, $18 \mathrm{~g}$ in $1 \mathrm{~L}$ distilled water, $\mathrm{pH}$ 7.2 7.4. Two media were used for re-screening, namely FM 2 [68]; Glucose, $10 \mathrm{~g}$; soluble starch, $30 \mathrm{~g}$; yeast powder, $2 \mathrm{~g}$; casein, $4 \mathrm{~g}$; $\mathrm{K}_{2} \mathrm{SO}_{4}, 8 \mathrm{~g}$; MOPS (3-[ $N$-morpholino]propanesulfonic acid), $5 \mathrm{~g}$; sea salts, 18 g; distilled water, $1 \mathrm{~L}$; pH 7.2-7.4; and FM 17 [69]; Glucose, 20 g; yeast powder, 5 g; casein, 5 g; $\mathrm{KNO}_{3}, 15 \mathrm{~g} ; \mathrm{CaCO}_{3}, 4 \mathrm{~g}$; sea salts, $18 \mathrm{~g}$; distilled water, $1 \mathrm{~L} ; \mathrm{pH}$ 7.2-7.4. All three media were autoclaved at $121^{\circ} \mathrm{C}$ for $20 \mathrm{~min}$.

Each of 2,041 purified isolates were transferred to a test tube $(30 \mathrm{~mm} \times 200 \mathrm{~mm}$ ) which contained $20 \mathrm{~mL}$ of the relevant fermentation medium, and cultured at $200 \mathrm{rpm}$, at an angle of $45^{\circ}$, for 7-10 days at $28{ }^{\circ} \mathrm{C}$. Crude extracts were prepared by adding $60 \mathrm{~mL}$ of methanol to each of the cultures and the extraction allowed to proceed for 2 weeks. One $\mathrm{mL}$ fractions of the resultant extracts were transferred to wells in deep 96-well plates, vacuum dried at $60{ }^{\circ} \mathrm{C}$, dissolved in $200 \mu \mathrm{L}$ DMSO and used in the biochemical screens and for cytotoxicity assay against HCT-116 cells.

\subsection{Biological assays}

Antimicrobial activity. The method used was modified from that of Hong and Xiao [70]. C. albicans ATCC 10231 and $S$. aureus ATCC 51650 were cultured overnight at $30{ }^{\circ} \mathrm{C}$ at $200 \mathrm{rpm}$ in YPD medium (glucose, 2\%; tryptone, $2 \%$; yeast extract, $1 \%$; $\mathrm{pH} 5.0 \sim 5.5$ ) and nutrient broth, respectively. The resultant cultures were diluted in the same media to $0.8-1.2 \times 10^{6} \mathrm{CFU} / \mathrm{mL}$, and $100 \mu \mathrm{L}$ aliquots of this inoculum were transferred to individual wells in a 96-well plates. Aliquots $(100 \mu \mathrm{L})$ of the fermentation broth supernatant of each of the isolates (fermented in the media above mentioned, and centrifuged at $10,000 \mathrm{rpm}$ at $4{ }^{\circ} \mathrm{C}$ ) were added to each of the wells. The two culture media were used as negative controls, and fluconazole and kanamycin as the positive controls for the anti- C. albicans and anti S. aureus assays, respectively. The 96-well plates were shaken at $200 \mathrm{rpm}$ for $24 \mathrm{~h}$ at $30{ }^{\circ} \mathrm{C}$ 
then assayed using a microplate spectrophotometer (Multiskan Mk3, Finland) at $570 \mathrm{~nm}$. The absorbance readings from each well were used to record bioactivities as "+", "++", or "+++" for higher or equal to 4-6, 6-8 and $8 \mu \mathrm{g} / \mathrm{mL}$ of standard, respectively. Serial dilutions of the antibiotics $(128,64$, $32,16,14,12,10,8,6,4,2$ and $1 \mu \mathrm{g} / \mathrm{mL}$ ) were used to generate standard curves.

Cell growth inhibition assay. Fractions $(100 \mu \mathrm{L})$ of each cell suspension $(30,000$ cells $/ \mathrm{mL})$ of the adherent cell line HCT-116 were dispensed into individual wells in 96-well plates which were incubated in McCoy's 5A medium (Sigma-Aldrich Corp., St. Louis, MO) at $37{ }^{\circ} \mathrm{C}$ in an incubator containing $5 \% \mathrm{CO}_{2}$ for 24 hours to allow surface attachment of the cells. Preparation in DMSO $(1 \mu \mathrm{L})$ were added and the 96-well plates incubated under the same conditions for 72 hours when $30 \mu \mathrm{L}$ MTT $(5 \mathrm{mg} / \mathrm{mL})$ was added to each of the wells and the plates incubated for 3 hours under the same conditions. The media were removed using a pipette and $100 \mu \mathrm{L}$ DMSO added to each of the wells of the plates. Readings were taken using a SpectraMAX340 microplate reader (Molecular Devices, Sunnyvale, CA) at an absorbance of $550 \mathrm{~nm}$, and a reference wavelength at $690 \mathrm{~nm}$. Adriamycin was used as the positive control. The $\mathrm{IC}_{50}$ value of each inhibitor was calculated in GraphPad Prism (GraphPad Software, San Diego, CA) using non-linear regression analysis and a sigmoidal dose response (variable slope) equation. Data were presented as mean \pm S.D. of $\geq 3$ independent experiments unless.

Biochemical assays. The construction, expression, purification, and enzymatic assays for protein tyrosine phosphatase 1B (PTP1B) and caspase 3 were carried following Shi [71] and Du [72], respectively. Aurora a [73], a recombinant protein kinase domain (125-391 amino acids according to AAH02499) was expressed in an Escherichia coli system; determination of the enzymatic activity was achieved using a Z-LYTE kinase assay kit (Invitrogen, Carlsbad, CA ). For primary screening, $2 \mu \mathrm{L}$ of the stock solution of each crude extract $(1 \mathrm{mg} / \mathrm{mL})$ in DMSO were transferred into individual wells of 96-well flat bottom plates to give a final concentration of $20 \mu \mathrm{g} / \mathrm{mL}$ of extract in $2 \%$ DMSO. After incubation with the enzymes for $15 \mathrm{~min}, 10$ times concentrated substrates were added to initiate the enzymatic reaction, and the resultant enzymatic activity normalized against the control ( $2 \% \mathrm{DMSO})$ to obtain the inhibition rate of the compound. When the inhibition rate was more than $50 \%$ at $20 \mu \mathrm{g} / \mathrm{mL}$, the dose-response inhibition assay of the compound was performed to determine the $50 \%$ percentage inhibition concentrations $\left(\mathrm{IC}_{50}\right)$.

\subsection{Identification of isolates}

Morphological characterization. The presumptive streptomycetes were inoculated onto oatmeal agar plates [62] prepared with and without sea salts, and onto peptone-yeast extract-iron agar [59] plates and incubated at $28{ }^{\circ} \mathrm{C}$ for 3 weeks and 4 days, respectively. After incubation, the oatmeal agar plates were examined by eye to record aerial spore mass color, substrate mycelial pigmentation, and the color of any diffusible pigments. The peptone-yeast extract-iron agar plates were examined for the production of melanin pigments 
Chemotaxonomy. Biomass was harvested from isolates grown at $28{ }^{\circ} \mathrm{C}$ for $3-7$ days on IM4 or IM6 agar plates for streptomycte-like and non-streptomycete-like strains, respectively. Isomers of diaminopimelic acid and diagnostic whole-organism sugars were detected by using the procedures described by Hasegawa et al. [74].

Extraction of DNA from pure cultures and PCR amplification. Total genomic DNA samples from 243 representative strains were extracted with the Fast DNA®SPIN Kit used for extracting community DNA from soil (Q-BIOgene, USA) using a protocol modified from that of the manufacturer ( Goodfellow, 2007). In short, approximately $0.5 \mathrm{~g}$ of each culture was suspended in TE buffer $(0.5 \mathrm{ml})$ and ribolised for $30 \mathrm{~s}$ at a speed of $5.5 \mathrm{~m} / \mathrm{s}$ following the addition of sterile glass beads $(0.5 \mathrm{~g}, 100$ mesh). The resultant preparations were extracted with an equal volume of chloroform: iso-amyl alcohol $(24: 1, \mathrm{v} / \mathrm{v})$ and centrifuged at $15,000 \mathrm{~g}$ for $5 \mathrm{~min}$ at 4 . The upper aqueous layers, which contained the DNA, were transferred to fresh tubes and used as template DNA. The PCR reactions were performed in a final volume of $25 \mu 1$ which was composed of template DNA $(1 \mu 1$ upper aqueous layer), $1.5 \mathrm{mM} \mathrm{MgCl}_{2}, 0.2 \mathrm{mM}$ of each dNTP, 200pM of primer Eubac27F and primer Eubac1492R[75], and $1 \mathrm{U}$ of $\mathrm{Taq}$ polymerase with the appropriate reaction buffer under the following conditions: initial denaturation at $95{ }^{\circ} \mathrm{C}$ for $5 \mathrm{~min}$, followed by 28 cycles of $95{ }^{\circ} \mathrm{C}$ for $50 \mathrm{~s}$, annealing at $52{ }^{\circ} \mathrm{C}$ for $50 \mathrm{~s}$, and $72{ }^{\circ} \mathrm{C}$ for $90 \mathrm{~s}$. The amplification products were separated by gel electrophoresis in $1 \%$ agarose gels which were stained with Goldview ${ }^{\mathrm{TM}}$ Nucleic Acid Stain (SBC, China).

Cloning, sequencing and phylogenetic analyses. The PCR products were blunt-end ligated to the plasmid vector pEGM (Promega, USA) and the ligation products transformed into competent $E$. coli DH5 $\alpha$ cells. The resultant clones were sequenced using an ABI 3730 Automated Sequencer (Applied Biosystems), and the sequences submitted to the BLAST function of GenBank. The cloned 16S rRNA gene sequences were aligned using CLUSTAL-X software [76] in the program BioEdit [77]. A neighbor joining [78] phylogenetic tree was generated using MEGA version 4.0 software [79], was evaluated in a bootstrap analysis [80] of 1,000 replicates; a distance matrix was generated using Kimura's 2-parameter model [81].

\section{Acknowledgements}

This research was supported by The National High Technology Development Project (863) (2007AA09Z415), The National Natural Science Foundation of China, Guangdong Province Union Key Project (U0633008), Program of New Century Excellent Talents, China Ministry of Education ( NCET-05-0756), and the Program for Social Profit, China Ministry of Science and Technology (2004DIB3J072). The authors are indebted to: Yan Li-ping, Hu Shen-cai, Lei Xiang-Lan, Xie Xin-Qiang, Hong Liang, Sheng Zhen-Guo, Xie Xiu-Chao, Wang Rong, Xu Xiao-Xiong, Wang Cheng, and Sui Jin-Lei for collecting the environmental samples, and for carrying out the selective isolation and primary identification of the isolates. We are also grateful to Gao Zhu-Fen and Li Xiao-Hui for preparing samples for screening. 


\section{References and Notes}

1. Talbot, G. H.; Bradley, J.; Edwards, J.E. Jr.; Gilbert, D.; Scheld, M.; Bartlett, J. G. Bad Bugs Need Drugs: An update on the development pipeline from the antimicrobial availability task force of the infectious diseases society of America. Clin. Infect. Dis. 2006, 42, 657-668.

2. Bentley, S.D.; Chater, K.F.; Cerdeno-Tarraga, A.M.; Challis, G. L.; Thompson, N.R.; James, K.D.; Harris, D.E.; Quail, M.A.; Kieser, H.; Harper, D; et al. Complete genome sequence of the model actinomycete Streptomyces coelicolor A3(2). Nature 2002. 417, 141-147.

3. Omura, S.; Ikeda, H.; Ishikawa, J.; Hanamoto, A.; Takahashi, C.; Shinose, M.; Takahashi, Y.; Horikawa, H.; Nakazawa, H.; Osonoe, T.; Kikuchi, H.; Shiba, T.; Sakaki, Y.; Hattori, M.; et al. Genome sequence of an industrial microorganism Streptomyces avermitilis: Deducing the ability of producing secondary metabolites. Proc. Natl. Acad. Sci. U.S.A. 2001, 98, 12215-12220.

4. Watve, M.G.; Tickoo, R.; Jog, M.M.; Bhole, B.D. How many antibiotics are produced by the genus Streptomyces. Arch. Microbiol. 2001, 176, 386-390.

5. Bérdy, J. Bioactive microbial metabolites. J. Antibiot. 2005, 58, 1-26.

6. Lazzarini, A.; Cavaletti, L.; Toppo, G.; Marinelli, F. Rare genera of actinomycetes as potential producers of new antibiotics. Antonie van Leeuwenhoek 2000, 78, 388-405.

7. Bredholt, H.; Fjærvik, E.; Johnsen, G.; Zotchev, S.B. Actinomycetes from sediments in the Trondheim Fjord, Norway: Diversity and biological activity. Mar. Drugs 2008, 6, 12-24.

8. Bull, A.T.; Stach, J.E.M.; Ward, A.C.; Goodfellow, M. Marine actinobacteria: perspectives, challenges, future directions. Antonie van Leeuwenhoek 2005, 87, 259-276.

9. Bull, A.T.; Stach, J.E. Marine actinobacteria: new opportunities for natural product search and discovery. Trends Microbiol. 2007, 15, 491-499.

10. Okoro, C.K.; Brown, R.; Jones, A.L.; Andrews, B.A.; Asenjo, J.A.; Goodfellow, M.; Bull, A.T. Diversity of culturable actinomycetes in hyper-arid soils of the Atacama Desert, Chile. Antonie van Leeuwenhoek in press.

11. Stach, J.E.M.; Maldonado, L.A.; Ward, A.C.; Goodfellow, M.; Bull, A.T. New primers for the class Actinobacteria: application to marine and terrestrial environments. Environ. Microbiol. 2003, $5,828-841$.

12. Stach, E.M.; Bull, A.T. Estimating and comparing the diversity of marine actinobacteria. Antonie van Leeuwenhoek 2005, 87, 3-9.

13. Ara, I.; Kudo, T.; Matsumoto, A.; Takahashi, Y.; Omura, S. Nonomuraea maheshkhaliensis sp. nov., a novel actinomycete isolated from mangrove rhizosphere mud. J. Gen. Appl. Microbiol. 2007, 53, 159-166.

14. Huang, H.; Lv, J.; Hu, Y.; Fang, Z.; Zhang, K.; Bao, S. Micromonospora rifamycinica sp. nov., a novel actinomycete from mangrove sediment. Int. J. Syst. Evol. Microbiol. 2008, 58, 17-20.

15. Pathom-aree, W.; Nogi, Y.; Sutcliffe, I.C.; Ward, A.C.; Horikoshi, K.; Bull, A.T.; Goodfellow, M. Williamsia marianensis sp. nov., a novel actinomycete isolated from the Mariana Trench. Int. J. Syst. Evol. Microbiol. 2006a, 56, 1123-1126.

16. Pathom-aree, W.; Nogi, Y.; Sutcliffe, I.C.; Ward, A.C.; Horikoshi, K.; Bull, A.T.; Goodfellow, M. Dermacoccus abyssi sp. nov., a piezotolerant actinomycete isolated from the Mariana Trench. Int. J. Syst. Evol. Microbiol. 2006b, 56, 1233-1237. 
17. Pathom-aree, W.; Nogi, Y.; Sutcliffe, I.C.; Ward, A.C.; Horikoshi, K.; Bull, A.T.; Goodfellow, M. Dermacoccus barathri sp. nov. and Dermacoccus profundi sp. nov., novel actinomycetes isolated from deep-sea mud of the Mariana Trench. Int. J. Syst. Evol. Microbiol. 2006c, 56, 2303-2307.

18. Tamura, T.; Sakane, T. Asanoa iriomotensis sp. nov., isolated from mangrove soil. Int. J. Syst. Bacteriol. 2005, 55, 725-727.

19. Yi, H.; Schumann, P.; Sohn, K.; Chun, J. Demequina aestuarii gen. nov., sp. nov., a novel actinomycete of the suborder Micrococcineae, and reclassification of Cellulomonas fermentans Bagnara et al. 1985 as Actinotalea fermentans gen. nov., comb. nov. Int. J. Syst. Evol. Microbiol. 2007, 57, 151-156.

20. Yi, H.; Schumann, P.; Sohn, K.; Chun, J. Serinicoccus marinus gen. nov., sp. nov., a novel actinomycete with L-ornithine and L-serine in the peptidoglycan. Int. J. Syst. Evol. Microbiol. 2004, 54, 1585-1589.

21. Maldonado, L.A.; Stach, J.E.M.; Pathom-aree, W.; Ward, A. C.; Bull, A.T.; Goodfellow, M. Diversity of cultivable actinobacteria in geographically widespread marine sediments. Antonie van Leeuwenhoek 2005, 87, 11-18.

22. Yu, Y.; Li, H.; Zeng, Y.; Chen, B. Isolation and phylogenetic assignation of actinomycetes in the marine sediments from the Arctic Ocean. Acta Oceanol. Sin. 2005, 24, 135-142.

23. Jensen, P.R.; Gontag, E. Mafnas, C.; Mincer, T.J.; Fenical, W. Culturable marine actinomycete diversity from tropical Pacific Ocean sediments. Environ. Microbiol. 2005, 7, 1039-1048.

24. Blunt, J.W.; Copp, B.R.; Hu,W.; Munro, M. H. G.; Northcote, P.T.; Prinsep, M. R. Marine natural products. Nat. Prod. Rep. 2007, 24, 31-86.

25. Fenical, W.; Jensen, P.R. Developing a new resource for drug discovery: marine actinomycete bacteria. Nature Chem. Biol. 2006, 2, 666-673.

26. Fiedler, H.P.; Bruntner, C.; Bull, A.T.; Ward, A.C.; Goodfellow, M.; Potterat, O.; Puder, C.; Mihm, G. Marine actinomycetes as a source of novel secondary metabolites. Antonie van Leeuwenhoek 2005, 87, 37-42.

27. Goodfellow, M.; Kumar, Y.; Labeda, D.P.; Sembiring, L. The Streptomyces violaceusinger clade: a home for streptomycetes with rugose ornamented spores. Antonie van Leeuwenhoek 2007, 92, 173-199.

28. Kumar, Y.; Goodfellow, M. Five new members of the Streptomyces violaceusniger 16S rRNA gene clade: Streptomyces castelarensis sp. nov., comb. nov., Streptomyces himastatinicus sp. nov., Streptomyces mordarskii sp. nov., Streptomyces rapamycinicus sp. nov. and Streptomyces ruanii sp. nov. Int. J. Syst. Evol. Microbiol. 2008, 58, 1369 - 1378.

29. Ward, A.C.; Goodfellow, M. Phylogeny and functionality: taxonomy as a roadmap to genes. In "Microbial Diversity and Bioprospecting”, Bull, A.T. Ed.; ASM Press, Washington, DC, USA; 2004, pp. 288-313.

30. Riedlinger, J.; Reicke, A.; Zahner, H.; Krismer, B.; Bull, A.T.; Maldonado, L.A.; Ward, A.C.; Goodfellow, M; Bister, B.; Bischoff, D.; Süssmuth, R.D.; Fiedler, H-P. Abyssomicins, inhibitors of the para-aminobenzoic acid pathway produced by the marine Verrucosispora strain AB-18-032. J. Antibiot. 2004, 57, 271-279. 
31. Williams, P.G.; Buchanan, G.O.; Feling, R.H.; Kauffman, C.A.; Jensen, P.R.; Fenical, W. New cytotoxic salinosporamides from marine actinomycete Salinispora tropica. J. Org. Chem. 2005, 70, 6196-6203.

32. Schneider, K.; Keller, S.; Wolter, F.E.; Roglin, L.; Beil, W.; Seitz, O.; Nicholson, G.; Bruntner, C.; Riedlinger, J.; Fiedler, H-P.; Süssmuth, R.D. Proximicins A, B, and C- antitumor furan analogues of netropsin from the marine actinomycete Verrocosispora induce upregulation of p53 and the cyclin kinase inhibitor p21. Angew. Chem. Int. Ed. 2008, 47, 3258-3261.

33. Williams, P.G. Panning for chemical gold: marine bacteria as a source of new therapeutics. Trends Biotechnol. 2009, 27, 45-52.

34. Zhang, Y.H.; Zhang, H.J.; Wu, F.; Chen, Y.H.; Ma, X.Q.; Du, J.Q.; Zhou, Z.L.; Li, J.Y.; Nan, F.J.; $\mathrm{Li}$, J. Isoquinoline-1,3,4-trione and its derivatives attenuate -amyloid-induced apoptosis of neuronal cells. FEBS J. 2006, 273, 4842-4852.

35. Johnson, T.O.; Ermolieff J.; Jirousek, M.R. Protein tyrosine phosphatase 1B inhibitors for diabetes. Nat. Rev., Drug. Discov. 2002, 1, 696-709.

36. Taylor, S.D.; Hill, B. Recent advances in protein tyrosine phosphatase 1B inhibitors. Expert Opin. Investig. Drugs 2004, 13, 199-214.

37. Zhang, W.; Hong, D.; Zhou, Y.Y.; Zhang, Y.N.; Shen, Q.; Li, J.Y.; Hu, L.H.; Li, J. Ursolic acid and its derivative inhibit protein tyrosine phosphatase $1 \mathrm{~B}$ enhancing insulin receptor phosphorylation and stimulating glucose uptake. Biochim. Biophys. Acta. 2006, 1760, 1505-1512.

38. Costanza, R.; d'Arge, R.; Groot, R.; Farberk, S.; Grasso, M.; Hannon, B.; Limburg, K.; Naeem, S.; O’Neill, R. V.; Paruelo, J.; Raskin, R. G.; Sutton, P.; van den Belt M. The value of the world's ecosystem services and natural capital. Nature 1997, 387, 253-260.

39. Wang, B.; Liang, S.; Zhang, W.; Zan, Q. Mangrove flora of the world. Acta Botanica Sinica 2003, $45,644-653$.

40. Hong, K.; Yan, B. Uncultured microorganisms in Hainan mangrove soil: diversity and functional genes. In "Microbes and the Environment: Perspective and Challenges", Liu S.J., Drake H. L., Eds.; Science Press: Beijing, China, 2008; pp. 52-58.

41. Hyde, K.D., Lee, S.Y. Ecology of mangrove fungi and their role in nutrient cycling: what gaps occur in our knowledge? Hydrobiologia 1995, 295, 107-118.

42. Yan, B.; Hong, K.; Yu, Z.; Archaeal communities in mangrove soil characterized by $16 \mathrm{~S}$ rRNA gene colones, J. Microbiol. 2006, 44, 566-571.

43. Eccleston, G. P.; Brooks, P. R.; Kurtböke, D. I. The occurrence of bioactive micromonosporae in aquatic habitats of the Sunshine Coast in Australia. Mar. Drugs 2008, 6, 243-261.

44. Han L, Huang XS, Sattler I, Fu HZ, Grabley S, Lin WH. Two new constituents from mangrove Bruguiera gymnorrhiza.J. Asian Nat. Prod. Res. 2007, 9, 327-31.

45. Huo, C.; Liang, H.; Tu, G.; Zhao, Y.; Lin, W. A new 5, 11-epoxymegastigmane glucoside from Acanthus ilicifolius. Nat. Prod. Res. 2008, 22, 896-900.

46. Wu, J.; Xiao, Q.; Huang, J.; Xiao, Z.; Qi, S.; Li, Q.; Zhang, S. Xyloccensin O and P, unique 8,9,30-phragmalin ortho esters from Xylocarpus granatum. Org. Lett. 2004, 6, 1841-1844.

47. Gao, H.; Hong, K.; Zhang, X.; Liu, H.W.; Wang, N. L.; Zhang, L.; Yao, X.S. Polyhydroxylated sterols and new sterol fatty esters from the mangrove fungus Aspergillus awamori exhibiting potent cytotoxic activity. Helv. Chim. Acta 2007, 90, 1165-1178. 
48. Krohn, K.; Steingröver, K.; Zsila, F. Five unique compounds: Xyloketals from the mangrove fungus Xylaria sp. from the South China Sea coast. J. Org. Chem. 2001. 66, 6252-6256.

49. Lin, Y.C.; Wu, X.Y.; Deng, Z.J.; Wang, J. Zhou, S.N.; Vrijmoed, L.L.P.; Jones, E.B.G. The metabolites of the mangrove fungus Verruculina enalia No. 2606 from a salt lake in the Bahamas. Phytochem. 2002, 59, 469-471.

50. Lin, Z.; Zhu, T.; Fang, Y.; Gu, Q. 1H and 13C NMR assignments of two new indolic enamide diastereomers from a mangrove endophytic fungus Aspergillus sp. Magn. Reson. Chem. 2008 46, 1212-1216.

51. Tang, J.S.; Gao, H.; Hong, K.; Yu, Y.; Jiang, M.M.; Lin, H.P.; Ye ,W.C.; Yao, X.S. Complete assignments of $1 \mathrm{H}$ and 13C NMR spectral data of nine surfactin isomers. Magn. Reson. Chem. 2007, 45, 792-796.

52. Xie, X.C.; Mei, W.L.; Zhao, Y.X.; Hong, K.; Dai, H.F. A new degraded sesquiterpene from marine actinomycete Streptomyces sp.0616208. Chinese Chem. Lett. 2006, 17, 1463-1465.

53. Lozupone, C.A.; Knight, R. Global patterns in bacterial diversity. Proc. Natl. Acad. Sci. USA 2007, 104, 11436-11440.

54. Liu, Z.; Shi, Y.; Zhang, Y.; Zhou, Z.; Li, W.; Huang Y.; Rodrigues, C.; Goodfellow, M. Classification of Streptomyces grieseus (Krainsky, 1914) Waksman and Henrici 1948 and related species and the transfer of "Microstreptospora cinerea" to the genus Streptomyces as Streptomyces yanii sp. nov. Int. J. Syst. Evol. Microbiol. 2005, 55, 1605-1610.

55. Antony-Babu, S.; Stach, J.E.M.; Goodfellow, M. Genetic and phenotypic evidence for Streptomyces griseus ecovars isolated from a beach and dune sand system, in Antonie van Leeuwenhoek 2008, 94, 63-74

56. Pisano, A. M; Sommer, J.M.; Lopez, M.M. Application of pretreatment for the isolation of bioactive actinomycetes from marine sediments. Appl. Microbiol. Biotechnol. 1986, 25, 285-288.

57. Hayakawa, M.; Iino, H.; Takeuchi, S.; Yamazaki, T. Application of a method incorporating treatment with chloramine-T for the selective isolation of Stretpsporangiaceae from soil. $J$. Ferment. Bioengin. 1997, 84, 599-602.

58. Takahashi, Y.; Matsumoto, A.; Seino, A.; Iwai, Y.; Omura, S. Rare actinomycetes isolated from desert soils. Actinomycetologica 1996, 10, 91-97.

59. Shirling, E.B.; Gottlieb, D. Methods for characterization of Streptomyces species, Int. J. Syst. Bacteriol. 1966, 16, 313-340

60. Ivantiskaya, L. P.; Singal,S. M.; Bibikova, M. V.; Vostrov S. N. Direct isolation of Micromonospora on selective media with gentamicin. Antibiotiki. 1978, 23, 690-692.

61. Williams, S.T.; Lanning, S., Wellington, E.M.H. Ecology of actinomycetes. In "The Biology of the Actinomycetes", Goodfellow, M.; Mordarski, M.; Williams S.T., Eds,; Academic Press: London, UK, 1984; pp. 481-528

62. Küster, E.; Williams, S. T. Media for the isolation of streptomycetes: starch casein medium. Nature 1964, 202, 928-929.

63. Tan, G.Y.A.; Robinson, S.; Lacey, E.; Goodfellow, M. Exploration of Amycolatopsis diversity in soil using genus-specific primers and novel selective media. Syst. Appl. Microbiol. 2006. 29, 557-569. 
64. Hayakawa, M.; Ohara, Y. Humic acid-vitamin agar, a new medium for the selective isolation of soil actinomycetes. J. Ferment. Technol. 1987, 65, 501-509.

65. Duangmal, K.; Ward, A.C.; Goodfellow, M. Selective isolation of members of the Streptomyces violaceoruber clade from soil. FEMS Microbiol. Lett. 2005, 245, 321-327.

66. Williams, S.T.; Davies, F.L. Use of antibiotics for selective isolation and enumeration of actinomycetes in soil. J. Gen Microbiol. 1965, 38, 251-261.

67. Garcia, G.D.; Romero, M.F.; Perez, B.J.; Garcia, D. T. Thiodepsipeptide isolated from a marine actinomycete WO9527730. 1999, Patent Number: US5681813.

68. Yu, J.S.; Hong, K.; Lin, H.P.; Yuan, G.J. Optimization study on fermentative medium for precursor of daptomycin A21978C produced by Streptomyces roseosporus NRRL 11397. J. Anhui Agric. Sci. 2008, 36, 7974-7976.

69. Chen, H.; Hong, K.; Zhuang, L.; Zhong, Q.P. Growth characteristics and fermentation condition optimization of mangrove actinomycete strain 0616167. Microbiology 2006, 33, 16-20.

70. Hong, K.; Xiao, C. A rapid method for detection of biological activity of anti- yeast-like pathogen. China Patent 2006, ZL03128096.

71. Shi, L.; Yu, H.P.; Zhou, Y.Y.; Du, J.Q.; Shen, Q.; Li, J.Y.; Li, J. Discovery of a novel competitive inhibitor of PTP1B by high-throughput screening. Acta Pharmacol. Sin. 2008, 29, 278-84.

72. Du, J.Q.; Wu, J.; Zhang, H.J.; Zhang, Y.H.; Qiu, B.Y.; Wu, F.; Chen, Y.H.; Li, J.Y.; Nan, F.J.; Ding, J.P.; Li, J. Isoquinoline-1,3,4-trione derivatives inactivate caspase-3 by generation of reactive oxygen species. J. Biol. Chem. 2008, 283, 30205-30215.

73. Gautschi, O.; Heighway, J.; Mack, P.C.; Purnell, P.R.; Lara, P.N.Jr.; Gandara, D.R. Aurora kinases as anticancer drug targets. Clin. Cancer. Res. 2008, 14, 1639-1648.

74. Hasegawa, T.; Takizawa, M.; Tanida, S. A rapid analysis for chemical grouping of aerobic actinoycetes. J. Gen. Appl. Microbiol. 1983, 329, 1319-1322.

75. Lane, D.J. 16S/23S rRNA sequencing. In "Nucleic Acid Techniques in Bacterial Systematics", Stackebrandt, E., Goodfellow, M., Eds.; Wiley: New York, NY, USA, 1991, pp. 115-175.

76. Thompson, J.D.; Gibson, T.J.; Plewniak, F.; Jeanmougin, F.; Higgins, D.G. The CLUSTAL _X windows interface: flexible strategies for multiple sequence alignment aided by quality analysis tools. Nucleic Acids Res. 1997, 25, 4876-4876.

77. Hall, U. A. BioEdit, a user-friendly biological sequence alignment editor and analysis program for Windows 95/98/NT. Nucl. Acids. Symp. Ser. 1999, 41, 95-98.

78. Saitou, N.; Nei, M. The neighbor-joining method: a new method for reconstructing phylogenetic trees. Mol. Biol. Evol. 1987, 4, 406-425.

79. Tamura, K.; Dudley, J.; Nei, M.; Kumar, S. MEGA4, Molecular Evolutionary Genetics Analysis (MEGA) software version 4.0. Mol. Biol. Evol. 2007, 24, 1596-1599.

80. Felsenstein, J. PHYLIP (phylogenetic inference package) version 3.2. Cladistics 1989, 5: 164-166.

81. Kimura, M. A simple method for estimating evolutionary rates of base substitutions through comparative studies of nucleotide sequences. J. Mol. Evol. 1980, 16, 111-120.

(C) 2009 by the authors; licensee Molecular Diversity Preservation International, Basel, Switzerland. This article is an open-access article distributed under the terms and conditions of the Creative Commons Attribution license (http://creativecommons.org/licenses/by/3.0/). 